DOI: 10.12797/Politeja.12.2015.39.01

\author{
Mieszko PAWLAK
}

Uniwersytet Jagielloński

mieszko.pawlak@gmail.com

\title{
TEORIA PRAWA \\ MARSYLIUSZA Z PADWY
}

\section{ABSTRACT Marsilius of Padua's Theory of Law}

The article presents the theory of law found in the writings of Marsilius of Padua, one of the greatest political thinkers of the late Middle Ages. The problem of law in the thought of Marsilius is one of the most controversial issues in Marsilian literature. The author of the article analyzes Marsilius' definition of law and his distinction between human law and divine law (i.e. revealed in Sacred Scripture). Also analyzed in detail is the issue of the relation between human law and justice, as well as human and divine law. The author states that Marsilius' theory was undoubtedly original and innovative, however he distances himself from the purely positivist interpretation of this theory, popular among some (especially Polish) researchers. According to the author, Marsilius' view on law, although highly original, bears more resemblance to the traditional natural law theories, rather than legal positivism in the classical sense.

Keywords: legal positivism, natural law, democracy, state, Church

Słowa kluczowe: pozytywizm prawniczy, prawo naturalne, demokracja, państwo, Kościół 
$\mathrm{P}_{\mathrm{d}}$ ostać Marsyliusza z Padwy od dawna cieszy się dużym zainteresowaniem badaczy dziejów myśli politycznej. Gdy blisko sto lat temu odkryto na nowo pisma tego autora, natychmiast dostrzeżono w nich zwiastun nowożytnych ujęć tematu państwa i idei suwerenności ludu. Wraz z następowaniem kolejnych dekad, jak z przekąsem zauważył Alan Gewirth, Marsyliusza okrzykiwano prekursorem wszelkich niemal doktryn politycznych: republikanizmu, demokratyzmu, absolutyzmu, liberalizmu, a nawet totalitaryzmu ${ }^{1}$. Równie doniosłą rolę przypisuje się Padewczykowi na polu jurysprudencji. Część badaczy widzi w nim ojca pozytywizmu prawniczego, stanowiska prawdziwie rewolucyjnego na tle średniowiecznej tradycji prawnej, bo definiujacego prawo jedynie w oparciu o kryteria formalne - taką interpretację podziela zdecydowana większość polskich autorów ${ }^{2}$. Z drugiej strony niektórzy badacze skłaniają się ku stanowisku przeciwnemu, podkreślającemu „antypozytywistyczny” wymiar koncepcji Padewczyka i jej głębokie zakorzenienie w refleksji wieków średnich ${ }^{3}$. W niniejszym artykule pragnę przyjrzeć się bliżej teorii prawa wyłożonej w pismach Marsyliusza, zwracając szczególną uwagę na budzącą tak wielkie kontrowersje kwestię relacji prawa stanowionego do norm ponadpozytywnych. Na początku chciałbym jednak scharakteryzować pokrótce twórczość tego myśliciela, aby uwypuklić miejsce i rolę koncepcji prawa w jego refleksji.

\section{ŻYCIE I DZIEŁO MARSYLIUSZA Z PADWY}

Marsyliusz Mainardini, bo tak brzmiało jego prawdziwe nazwisko, urodził się nie później niż w 1287 roku w Padwie. Przypuszcza się, że początkowo studiował sztuki wy-

1 Por. A. Gewirth, Marsilius of Padua and Medieval Political Philosophy, New York 1951, s. 3-6, Marsilius of Padua, the Defender of Peace, $\mathrm{nr} 1$.

2 Por. A. Wójtowicz, Model wtadzy państwowej Marsyliusza z Padwy, Katowice 1977, s. 115-116, Prace Naukowe Uniwersytetu Ślaskiego w Katowicach, nr 187; J. Baszkiewicz, Myśl polityczna wieków średnich, Poznań 2009, s. 182-186, Czas i Myśl; L. Dubel, Koncepcja wtadzy prawodawczej Marsyliusza z Padwy, [w:] Konstytucyjny ustrój państwa. Księga jubileuszowa profesora Wiestawa Skrzydty, red. T. Bojarski, E. Gdulewicz, J. Szreniawski, Lublin 2000, s. 54-62; T. Żyro, Wola polityczna. Siedem prób z filozofii praktycznej, Warszawa 2008, s. 170-171, Wspótczesna Myśl Humanistyczna. Polskie Spojrzenia; A. Pieniążek, Suwerenność - problemy teorii i praktyki, Warszawa 1979, s. 21-22; A. Wielomski, Teokracja papieska 1073-1378. Myśl polityczna papieży, papalistów i ich przeciwników, Radzymin-Warszawa 2011, s. 519, Biblioteka Konserwatyzm.pl.

3 Por. H.-Y. Lee, Political Representation in the Later Middle Ages. Marsilius in Context, New York 2008, s. 107-109; C.J. Nederman, Marsyliusz z Padwy, [w:] Myśliciele polityczni. Od Sokratesa do wspótczesności, red. D. Boucher, P. Kelly, przeł. A. Dąbrowska, T. Sieczkowski, Kraków 2008, s. 178-179, 185, Polityka - Wydawnictwo Uniwersytetu Jagiellońskiego; tenże, Knowledge, Consent and the Critique of Political Representation in Marsiglio of Padua's "Defensor Pacis”, „Political Studies” 1991, nr 39, s. 32; tenże, Nature, Justice, and Duty in the „Defensor Pacis”. Marsiglio of Padua's Ciceronian Impulse, „Political Theory" 1990, Vol. 18, nr 4, s. 629-632; tenże, Community and Consent. The Secular Political Theory of Marsiglio of Padua's „Defensor Pacis”, Lanham 1995, s. 79-83; F. Maiolo, Medieval Sovereignty. Marsilius of Padua and Bartolus of Saxoferrato, Delft 2007, s. 212-216; J. Canning, Ideas of Power in the Late Middle Ages, 1296-1417, New York-Cambridge 2011, s. 95-98; tenże, The Role of Power in the Political Thought of Marsilius of Padua, „History of Political Thought” 1999, Vol. 20, nr 1, s. 30-31. 
zwolone, a być może i medycynę, na padewskim uniwersytecie, dalsze studia odbywał natomiast na uczelni w Paryżu, gdzie w latach 1312-1313 pełnił nawet funkcję rektora. Podobnie jak większość ówczesnych mieszkańców Padwy Marsyliusz związany był początkowo ze stronnictwem gwelfów, jednak z nie do końca jasnych powodów w 1319 roku zmienił swą afiliację polityczną, przystępując do frakcji gibelinów. Pięć lat później ukazało się jego główne dzieło, radykalnie antypapieski traktat poświęcony relacjom między państwem a Kościołem, zatytułowany Defensor pacis (Obrońca pokoju). Choć Marsyliusz opublikował swój traktat anonimowo, jego autorstwo nie dało się długo utrzymać w tajemnicy. W roku 1327 Jan XXII uznał Defensor pacis za dzieło heretyckie, a jego autora obłożył karą ekskomuniki. Padewczyk nie był bynajmniej skory do wyrzeczenia się swych poglądów i okazania skruchy. Przeciwnie, podjął się on próby przekucia swych idei w czyn u boku Ludwika Bawarskiego, którego wspierał w walce z papiestwem i w staraniach o cesarski tron. Marsyliusz pozostał na jego dworze do końca swych dni. Data jego śmierci nie jest znana, możemy jednak określić jej terminus ante quem, bowiem w wygłoszonej w kwietniu 1343 roku przemowie papież Klemens VI wypowiadał się o Padewczyku jako zmarłym ${ }^{4}$.

Marsyliusz nie pozostawił po sobie szczególnie licznych dzieł. Kilka lat po opublikowaniu Obrońcy pokoju ukazało się mniejsze dzieło De translatione Imperii opisujące dzieje cesarstwa, a w ostatnich latach życia napisał także trzy pisma poświęcone kwestii małżeństwa, które później weszły w skład traktatu Defensor minor ${ }^{5}$. Największe znaczenie w jego dorobku miał oczywiście Defensor pacis, w którym to dziele Marsyliusz zawarł systematyczny wykład zagadnienia dwu władz - doczesnej i duchowej. Problem ten obecny był jednak także w pozostałych pismach Padewczyka, przede wszystkim w Defensor minor, i nie będzie przesadą powiedzieć, że owa kwestia stanowiła naczelny temat całej jego refleksji. Dlaczego Marsyliusz przywiązywał tak wielką wagę do tego zagadnienia? Odpowiedź na to pytanie znajdziemy w samym Obrońcy pokoju. Otóż, zgodnie z deklaracją autora, zasadniczym celem, jaki przyświecać miał temu dziełu, było zwalczenie pewnej przewrotnej opinii (opinio perversa), której konsekwencje postrzegał on jako szkodliwe dla każdej społeczności ludzkiej, a w istocie zgubne dla całego rodzaju ludzkiego ${ }^{6}$. Owym brzemiennym w fatalne skutki poglądem było przekonanie o przysługującej papieżom pełni władzy (plenitudo potestatis), przez którą Marsyliusz

4 Najnowsze i najbardziej szczegółowe informacje na temat życia Marsyliusza z Padwy podają Frank Godthardt i William J. Courtenay. Por. F. Godthardt, The Life of Marsilius of Padua, [w:] A Companion to Marsilius of Padua, red. G. Moreno-Riaño, C.J. Nederman, Leiden 2012, s. 13-55, Brill's Companions to the Christian Tradition, Vol. 31; W.J. Courtenay, Marsilius of Padua at Paris, [w:] A Companion..., s. 57-70.

5 Padewczykowi przypisuje się niekiedy autorstwo trzech mniejszych pism metafizycznych, napisanych zapewne jeszcze przed ukazaniem się Obrońcy pokoju, ale jak dotąd nie udało się ustalić jednoznacznie, czy Marsyliusz istotnie napisał którekolwiek z tych dziełek, a najnowsze badania w tym zakresie skłaniają raczej do wniosków przeciwnych. Por. G. Briguglia, The Minor Marsilius. The Other Works of Marsilius of Padua, [w:] A Companion..., s. 266-268; W.J. Courtenay, Marsilius of Padua..., s. 61-65.

6 Por. Marsyliusz z Padwy, Obrońca pokoju, przeł., oprac. i wstęp W. Seńko, Kęty 2006, I.1.3, s. 39, Biblioteka Europejska - Antyk. 
rozumiał sprawowanie najwyższej jurysdykcji operującej przymusem (iurisdictio coactiva) nad wszystkimi ludźmi, w tym nad władcami świeckimi .

Padewczyk był zdania, że formuła plenitudo potestatis wymyślona została przez papieży powodowanych żądzą władzy, rozbudzoną przez niefortunną donację Konstantyna. Biskupi rzymscy przedstawiali ją jako dar Chrystusa udzielony Piotrowi i jego następcom, dzięki czemu uważali się oni za upoważnionych nie tylko do nieustannego wtrącania się w sprawy doczesne, ale i do sukcesywnego uzurpowania sobie uprawnień kolejnych władców celem przejęcia faktycznego zwierzchnictwa nad całym światem ${ }^{8}$. To wszystko prowadzić miało jego zdaniem do prawdziwie katastrofalnych skutków, zwłaszcza w Italii, którą papieże podtrzymywali rzekomo w stanie faktycznej anarchii poprzez wstrzymywanie ustanowienia cesarza, ściągając w ten sposób na ów kraj liczne waśnie i podziały prowadzące do upadku wspólnot politycznych, w rezultacie czego jego mieszkańcy pozbawieni zostali możliwości odrodzenia się w następnych pokoleniach, majętności ich zostaty strawione, domy ograbione i zburzone, miasta wielkie i stawne pozbawione swoich mieszkańców, pozostaty puste, pola nieuprawiane staty sie już ugorami i odwykty od przynoszenia normalnych plonów; i to nad czym powinno się najbardziejptakać: zaniknąt nieomal zupetnie nie sprawowany tam kult Boży, samotne kościoty i światynie pozostaty bez rektorów, czyli pasterzy dusz?.

Oczywiście tę charakterystykę plenitudo potestatis i jej konsekwencji należy traktować z dużą rezerwą. W istocie nosi ona wszelkie znamiona antyklerykalnej propagandy, zwłaszcza że towarzyszyło jej wezwanie do podjęcia natychmiastowych działań w celu zwalczenia tej - jak pisał - zgubnej zarazy (perniciosa pestis), aby nie zajęła i nie doprowadziła do zniszczenia pozostałych królestw chrześcijańskich. Działania te obejmować miały nie tylko ujawnienie złowrogiej roli plenitudo potestatis za pomocą słowa, ale też poskromienie jej orędowników poprzez dziatania zewnętrzne (exteriori opera), a więc przy użyciu siły ${ }^{10}$. Tymi, którzy mieli podjąć owe działania, byli oczywiście ówcześni władcy świeccy, a zwłaszcza wspomniany Ludwik Bawarski - Marsyliusz deklarował wprost, że Obrońcę pokoju napisał po to, by wspomóc Bawarczyka w jego politycznych działaniach ${ }^{11}$. Należy więc wnosić, że aktywności intelektualnej Padewczyka nie przyświecał cel teoretyczny, ale raczej polityczny. Dzieło Marsyliusza stanowić miało przede wszystkim, jak to ują Cary J. Nederman, wezwanie do działania, zachętę skierowaną do władców świeckich, by podjęli się reformy faktycznych relacji między dwiema władzami, nie po to jednak, by położyć tamę rzekomej wszechwładzy papieży, gdyż ta w dobie niewoli awiniońskiej była fikcją, a raczej by podporządkować państwu całą domenę eklezjalną, trwale znosząc w tym wszelką zależność porządku politycznego od Kościoła i duchowieństwa ${ }^{12}$. W swoich pismach Padewczyk starał się więc wykazać, że państwo (civitas) winno być niezależne od Kościoła.

Por. tamże, II.23.3, s. 325 .

8 Por. tamże, I.19.8-11, s. 118-120; tamże, II.22.20, s. 322-323; tamże, II.23.5-11, s. 326-329.

9 Tamże, II.26.19, s. 369-370. Por. tamże, I.19.12, s. 120-121.

10 Por. tamże, I.19.13, s. 121-122.

11 Por. tamże, I.1.6, s. 40-41.

12 Por. C.J. Nederman, Community and Consent..., s. 14-19; F. Godthard, The Life of Marsilius..., s. 19-22. 
Nie ulega wątpliwości, że zagadnienie prawa odgrywało w refleksji Marsyliusza rolę szczególną. Zadanie, jakie postawił sobie autor Obrońcy pokoju, wymagało sformułowania takiej teorii prawa, która zabezpieczałaby autonomię norm ludzkich stanowionych we wspólnocie politycznej. Wedle tradycyjnego średniowiecznego poglądu prawo ludzkie (lex humana) nie było bowiem zbiorem norm niezależnym od kontekstu religijnego czy metafizycznego, ale raczej stanowiło konkretyzację praw wyższego rzędu, zastosowanie norm prawa Bożego do rzeczywistości ludzkiej. Klasycznym przykładem takiego stanowiska była teoria prawa św. Tomasza z Akwinu, zgodnie z którą prawa ludzkie stanowią partykularne rozporządzenia wywiedzione przez rozum ludzki z prawa naturalnego (lex naturalis), czyli Boskiego prawa wiecznego partycypującego w rozumnym stworzeniu ${ }^{13}$. W konsekwencji wszelkie normy ludzkie niezgodne z prawem naturalnym nie są właściwie prawem, ale raczej pogwałceniem prawa (corruptio legis) ${ }^{14}$. Zgodność z prawem wyższego rzędu jest więc konstytutywnym elementem legis humanae. Takie stanowisko było dla Marsyliusza nie do zaakceptowania, ponieważ wiązało się z możliwością stosunkowo łatwego podważenia porządku prawnego civitas poprzez stwierdzenie jego niezgodności z normami Boskimi, zwłaszcza przez duchownych, będących niejako z urzędu nauczycielami prawa Bożego. Padewczyk musiał więc zaproponować nową koncepcję prawa, odbiegającą nie tylko od ujęcia Akwinaty, ale i od całej jurysprudencji średniowiecznej.

\section{POJĘCIE PRAWA I JEGO RODZAJE}

Punktem wyjścia teorii Marsyliusza było stwierdzenie, że prawo oznacza naukę czy powszechny osąd o tym, co sprawiedliwe i korzystne społecznie, oraz o tym, co się temu sprzeciwia, przy czym można je rozumieć dwojako - samo w sobie, czyli po prostu jako naukę, albo też jako pewien nakaz zmuszający (praeceptum coactivum) do jej przestrzegania za pomocą kar i nagród. Według Padewczyka właśnie to ostatnie znaczenie prawa jest najwłaściwsze ${ }^{15}$. Prawo właściwie rozumiane nie jest więc rozporządzeniem rozumu, jak u św. Tomasza, ale nakazem popartym przymusem, a ściślej zarządzeniem prawodawcy zawierającym taki nakaz. Innymi słowy, danej normie przysługuje miano prawa, jeśli została uchwalona przez właściwy podmiot (prawodawca) i zawiera pewien nakaz obligujący ludzi do wykonania lub zaniechania określonych działań pod groźbą kary ${ }^{16}$.

13 Por. św. Tomasz z Akwinu, Summa Theologiae, I-II, q. 91, a. 2-3, [online] www.corpusthomisticum. org, 21 XII 2014.

14 Por. tamże, I-II, q. 95, a. 2.

15 Por. Marsyliusz z Padwy, Obrońca pokoju, I.10.3-4, s. 66-67; tenże, Defensor minor, 13.3, [w:] tenże, Oeuvres mineures, red. C. Jeudy, J. Quillet, Paris 1979, s. 268-270, Sources d'Histoire Médiévale.

16 Por. tenże, Obrońca pokoju, II.12.3, s. 207-208. Dodajmy jednak, że wedle Marsyliusza prawa mogą ponadto zawierać nakazy i zakazy pozbawione sankcji. Padewczyk pisze, że istnieja jeszcze inne zarządzenia [...] wyrażone w prawach albo tylko z nich wynikające, odnoszace się do jednego lub do wielu czynów, spetnianych albo zaniechanych, które nie pociagaja za soba żadnej kary, jak na przyktad spetnienie lub 
Widzimy zatem, że konstytutywnym elementem prawa jest jego uchwalenie przez uprawniony do tego podmiot oraz możliwość stosowania przymusu w celu zabezpieczenia jego wykonywania. W tym miejscu należy jednak postawić pytanie o to, kto jest owym podmiotem, który może w uprawniony sposób ustanawiać normy prawne. Otóż wedle Marsyliusza rolę tę pełni w społeczności ludzkiej sam lud (populus), czyli ogół obywateli lub jego znaczna część (universitas ${ }^{17}$ civium seu eius pars valentior), który tworzy prawa bezpośrednio na powszechnym zgromadzeniu obywateli albo też za pośrednictwem jakiegoś innego podmiotu, będącego wtedy prawodawcą wtórnym z upoważnienia ludu jako prawodawcy pierwotnego (secundum primi legislatoris auctoritatem $)^{18}$. Dla Padewczyka zatem to ogół obywateli jest - jak to określa - prawodawcą ludzkim (legislator humanus), będącym właściwym źródłem prawa we wspólnocie politycznej.

Marsyliuszowe ujęcie prawodawcy wymaga szerszego omówienia. Na pierwszy rzut oka przytoczona wyżej definicja skłania do interpretowania myśli Padewczyka w duchu demokratycznym. Co prawda Marsyliusz trochę zaciemnia ten obraz, niefortunnie przytaczając Arystotelesowską definicję obywatela jako tego, kto partycypuje we wspólnocie obywatelskiej w jej części rządzącej zgodnie ze swoją pozycją (secundum gradum suum), co może sugerować redukcję grona obywatelskiego do aktualnych wykonawców funkcji rządzącej, a nie do osób do tego uprawnionych, jak u Stagiryty ${ }^{19}$. Jest jednak zupełnie jasne, że autorowi Defensor pacis zależało na jak najbardziej inkluzywnym ujęciu obywatelstwa i prawodawcy, o czym świadczą rozwlekłe wywody zmierzające do wykazania, iż to cała wspólnota tworzy prawa najlepsze, a zarazem takie, które będą najbardziej rygorystycznie przestrzegane. Pierwszą z tych tez uzasadnia Marsyliusz następująco: jak naucza Arystoteles, najlepsze prawa to prawa stanowione dla wspólnego pożytku obywateli, ten zaś najlepiej rozpoznaje cała wspólnota, ponieważ każda całość jest większa pod względem wagi i sprawności (virtute) od jakiejkolwiek jej części ${ }^{20}$. Dowód drugiej tezy zasadza się na przekonaniu, iż bardziej przestrzegane są te prawa, które się samemu sobie narzuciło, dlatego też gdy uchwalanie prawa w państwie wymaga zatwierdzenia przez wszystkich, wówczas każdy jest bardziej skłonny do przestrzegania go $^{21}$.

Wydaje się zatem uzasadnione twierdzenie, iż według Marsyliusza prawodawcą jest cała wspólnota obywateli rozumiana inkluzywnie, bo obejmująca wszystkie części civi-

zaniechanie aktu szczodrobliwości i wiele innych podobnych aktów. Takie czyny nazywają sięściśle dozwolone prawem (lege permissa) [...] (tamże, II.12.4, s. 208).

17 Termin universitas tłumaczę tu jako „ogół”, ale trzeba wziąć pod uwagę, że w czasach Marsyliusza miał on wyraźne konotacje prawne, a mówiąc ściślej - oznaczał po prostu zbiorowe ciało mające osobowość prawną niezależną od podmiotowości prawnej jego członków. Por. B. Tierney, Religion, Law, and the Growth of Constitutional Thought, 1150-1650, Cambridge 2008, s. 19.

18 Por. np. Marsyliusz z Padwy, Obrońca pokoju, I.12.3, s. 76; tamże, III.2.6, s. 430.

19 Por. tamże, I.12.4, s. 76-77; Arystoteles, Polityka, przeł., wstęp i koment. L. Piotrowicz, wstęp M. Szymański, Warszawa 2008, 1275a-1275b, s. 76-78; tamże, 1277b, s. 83; tamże, 1283b, s. 96.

20 Por. Marsyliusz z Padwy, Obrońca pokoju, I.12.5, s. 77-78; Arystoteles, Polityka, 1281b, s. 90-91; tamże, 1282a, s. 91-92; tamże, 1283b, s. 95.

21 Por. Marsyliusz z Padwy, Obrońca pokoju, I.12.6, s. 78. 
tas, choć z pominięciem dzieci, niewolnych, obcych i kobiet ${ }^{22}$. $Z$ drugiej strony należy jednak mieć na uwadze, że Marsyliusz łagodził nieco ów demokratyczny charakter w swym opisie procesu legislacyjnego. Padewczyk stał na stanowisku, iż zdolność odkrywania (invenire) prawa nie przysługuje wszystkim w równym stopniu, choć niemal każdy zdolny jest oceniać prawa odkryte przez innych, a także rozstrzygać (discernere), czy należy je poddać jakimś zmianom, wobec czego rolą ludu w tworzeniu prawa nie powinno być odkrywanie praw, ale raczej zatwierdzanie tego, co już zostało odkryte ${ }^{23}$. Legislator humanus nie zajmuje się więc prawotwórstwem w sensie ścisłym, ale ratyfikuje i ewentualnie modyfikuje projekty przedłożone przez znacznie węższe grono ludzi, których Marsyliusz nazywa po prostu roztropnymi (prudentes) $)^{24}$. Kluczową rolę w procesie prawodawczym odgrywa zatem nie ogół obywateli, ale jedynie ta ich część, która przewyższa innych cnotą roztropności.

Trzeba też pamiętać, że Padewczyk przewidywał - jak wspomniałem - możliwość delegacji przez lud swych kompetencji legislacyjnych na jakieś inne ciało, w tym nawet na osobę władcy. W istocie, autor Defensor pacis nie tylko dopuszczał takie rozwiązanie, ale traktował je jako fakt historyczny, przynajmniej w odniesieniu do Imperium Romanum, którego pierwotny prawodawca przenieść miał na swego władcę całość uprawnień legislacyjnych ${ }^{25}$. Dlatego też w swych pismach Marsyliusz termin legislator humanus odnosił również do cesarzy, których określał nawet mianem najwyższych prawodawców ludzkich (legislator humanus superiore carens) ${ }^{26}$.

Wreszcie wspomnieć należy także o istotnej niejasności pojęcia pars valentior, będącego od dawna przedmiotem sporu badaczy myśli Padewczyka. Nie ulega wątpliwości, że mówiąc o znacznej części, Marsyliusz nie miał na myśli zwykłej numerycznej większości, ponieważ mówił wyraźnie, że pars valentior musi uwzględniać nie tylko liczbę, ale i jakość osób we wspólnocie ${ }^{27}$. W tekście Defensor pacis znajdujemy ponadto sugestię, że pars valentior oznacza wszystkich obywateli za wyjątkiem tych, którzy mają na tyle spaczoną naturę (naturam orbatam), że nie są w stanie porozumieć się z pozostałymi odnośnie do tego, co korzystne dla całej wspólnoty ${ }^{28}$. Można stąd wnosić, że w gruncie rzeczy pars valentior równoznaczna jest z ogółem, zwłaszcza że wedle Padewczyka

22 Por. tamże, I.12.4, s. 76.

23 Por. tamże, I.13.3, s. 81-82; tamże, I.13.7, s. 84. Zob. także: C.J. Nederman, Community and Consent..., s. 63-66; G. Moreno-Riaño, C.J. Nederman, Marsilius of Padua's Principles of Secular Politics, [w:] A Companion..., s. 118-122.

24 Por. Marsyliusz z Padwy, Obrońca pokoju, I.12.2, s. 75-76; tamże, I.13.8, s. 84-85.

25 Marsyliusz nawiązuje tu nie wprost do tzw. lex regia, czyli fragmentu Kodeksu Justyniana mówiącego o przekazaniu przez lud rzymski pełni jego władzy w ręce imperatorów. Zob. szerzej: W. Ullmann, A History of Political Thought. The Middle Ages, Harmondsworth 1968, s. 214-215; J. Canning, A History of Medieval Political Thought, 300-1450, London-New York 1996, s. 8-9; H.-Y. Lee, Political Representation..., s. 63-71.

26 Por. np.: Marsyliusz z Padwy, Obrońca pokoju, II.18.8, s. 286-287; II.21.1-2, s. 299-300; tenże, Defensor minor, 1.7, s. 176.

27 Por. tenże, Obrońca pokoju, I.12.3, s. 76.

28 Por. tamże, I.12.5, s. 77-78. 
większość obywateli [...] nie jest ani zta, ani pozbawiona rozeznania. Wszyscy bowiem lub większość z nich jest zdrowa na umyśle i rozsądna, pragnie wtaściwego ustroju politycznego $i$ tego, co jest konieczne do jego zachowania, a więc praw $[. . .]^{29}$. Problem w tym, że Marsyliusz mówił także, iż pars valentior należy rozumieć w zgodzie ze zwyczajami poszczególnych państw (secundum politiarum consuetudinem), a to prowadzi do wniosku, że znaczenie tego terminu jest $\mathrm{w}$ istocie dowolne - pojęcie znacznej części odnosić się może do każdego podmiotu, w tym nawet - jak twierdzi Michael J. Wilks - do siedmioosobowego kolegium elektorskiego w Cesarstwie ${ }^{30}$.

Marsyliuszowe pojęcie prawodawcy ludzkiego cechuje zatem wyraźna niejednoznaczność, która w moim odczuciu wyklucza jednostronnie demokratyczną interpretację. Biorąc wszakże pod uwagę praktyczny czy też polityczny charakter refleksji Padewczyka, należy moim zdaniem zgodzić się z tezą Conala Condrena, iż ta niejednoznaczność była zamierzona ${ }^{31}$. Marsyliuszowi niewątpliwie zależało na powierzeniu ludowi roli pierwotnego prawodawcy świeckiego, bo pozwalało mu to osłabić pretensję duchowieństwa do ingerencji w proces legislacyjny. Jak jednak wspomniałem, myśl Padewczyka stanowiła wezwanie do działania skierowane do wszystkich ciał politycznych i ich władców, zwłaszcza zaś do cesarza, wobec czego autor Defensor pacis nie miał bynajmniej zamiaru wyciągać ostatecznych wniosków z tych demokratycznych przesłanek i przekreślać w ten sposób możliwości realizacji swego projektu. Krótko mówiąc, Marsyliusz świadomie posługiwał się niejednoznacznym pojęciem prawodawcy w celu zdobycia jak najszerszego wsparcia dla jego polityczno-eklezjalnych postulatów.

Powyższe rozważania odnosiły się do prawa ludzkiego, ustanawianego we wspólnocie politycznej w celu nadawania właściwej miary działaniom człowieka, dzięki czemu wszystkie części państwa mogą być zachowane w należytym istnieniu (in esse debito), zaś całe państwo może trwać w pokoju (tranquillitas) ${ }^{32}$. Jednak prawo to reguluje tylko te czyny, które mogą przynieść szkodę innym, a zarazem - jak mówił Marsyliusz - pochodzą z ludzkich władz poznawczych i pożądawczych, czyli są czynami świadomymi. Autor Defensor pacis nazywał je przechodnimi (actiones transeuntes), ponieważ ich skutki przechodzą niejako na inne podmioty, w przeciwieństwie do czynów immanentnych, czyli pozostających w całości w podmiocie wykonującym, którymi są jego zdaniem myśli i pragnienia (cogitationes et hominum desideria seu affectiones), niepodlegające ludzkiej jurysdykcjii3 ${ }^{33}$. Ale że te ostatnie czyny także mają wpływ na stan państwa, przeto - jak twierdził Marsyliusz - niektórzy filozofowie skorzy byli do ustanawiania

29 Por. tamże, I.13.3, s. 81-82. W ten właśnie sposób termin ów rozumie m.in. C.J. Nederman czy H.-Y. Lee. Por. C.J. Nederman, Community and Consent..., s. 87; H.-Y. Lee, Political Representation..., s. 119-122.

30 Por. Marsyliusz z Padwy, Obrońca pokoju, I.12.4, s. 76-77. Zob. także: M.J. Wilks, The Problem of Sovereignty in the Later Middle Ages. The Papal Monarchy with Augustinus Triumphus and the Publicists, Cambridge 2008, s. 194-199; C. Condren, Marsilius of Padua's Argument from Authority. A Survey of Its Significance in the „Defensor Pacis”, „Political Theory” 1977, Vol. 5, nr 2, s. 211-212.

31 Por. C. Condren, Marsilius of Padua's..., s. 211-212.

32 Por. Marsyliusz z Padwy, Obrońca pokoju, I.2.3, s. 42-43; tamże, I.15.11, s. 95.

33 Por. tamże, I.5.4, s. 49; tamże, I.5.7, s. 50. 
osobnych norm religijnych dla ich miarkowania. Istnieja bowiem czyny - pisal - których prawodawca nie może osądzać wedle praw ludzkich, jako że niepodobna udowodnić ich stuszności i niestuszności. Nie jest to jednak niewiadome Bogu, wobec tego mędrcy ci uczynili dawca tych praw Boga, który nakazat ich przestrzeganie pod groźbą wiecznej kary wymierzanej za zte czyny lub obietnica wiecznej nagrody za uczynki dobre ${ }^{34}$.

Normy te miały, rzecz jasna, ludzkie pochodzenie, a jedyną racją ich istnienia było dobro ludzkich poczynań jednostkowych i spotecznych, od którego niemal catkowicie zalezy spokój i tad spoteczny [tranquillitas - przyp. M.P.], a w rezultacie i samowystarczalne życie $w$ teraźniejszym świecie ${ }^{35}$. Marsyliusz deklarował jednak wiarę $\mathrm{w}$ istnienie prawdziwego prawa Bożego (lex divina), objawionego najpierw przez Mojżesza, potem zaś w pełni przez Chrystusa w postaci prawa Ewangelii. Przestrzeganie tego prawa, odnoszącego się zarówno do czynów przechodnich, jak i immanentnych, uwalnia ludzi od kary wiecznego potępienia, która ciąży na nich wskutek grzechu pierworodnego, a dzięki łasce płynącej ze zbawczej męki i śmierci Syna Bożego umożliwia zasłużenie na wieczną szczęśliwość $\mathrm{w}$ przyszłym świecie ${ }^{36}$. Lex divina jest prawem w ścisłym tego słowa znaczeniu, ponieważ jest ono zarządzeniem prawodawcy zawierającym nakazy poparte przymusem. Różnica w stosunku do prawa ludzkiego polega na tym, że prawodawcą jest tu sam Bóg - Jezus Chrystus, a zastosowanie przymusu ma miejsce dopiero w przyszłym świecie, kiedy to Sędzia i Dawca tego prawa wykona swój osąd, nagradzając tych, którzy stosowali się do Jego rad i przykazań, a karząc występnych ${ }^{37}$. W zasadzie więc prawo Boże jest prawem wyłącznie w odniesieniu do rzeczywistości pozadoczesnej, na tym świecie natomiast jest ono bardziej nauką niż prawem sensu proprio. Padewczyk pisał bowiem, iż prawo Ewangelii ustanowione przez Chrystusa może w dwojaki sposób odnosić się do cztowieka. Po pierwsze: może ono dotyczyć zachowania i sposobu zycia cztowieka tutaj na ziemi, i w tym znaczeniu jest ono bardziej doktryna teoretyczna lub praktyczna (badźjedna i druga) w jej wielorakich aspektach niż prawem wśsistym tego stowa znaczeniu [...]. Po drugie: Pismo święte, czyli prawo Ewangelii, może się odnosić do bytowania cztowieka w przysztym, a nie na tym świecie i tylko w przysztym życiu cztowiek będzie podlegat karze i cierpieniu za przekraczanie tego prawa w obecnym życiu. W tym dopiero aspekcie prawo Ewangelii zyskuje miano prawa w sensie najściślejszym $[. . .]^{38}$. Autor Defensor pacis przekonywał, że taka była wola samego Chrystusa, który chciał w ten sposób pozostawić wszystkim ludziom możliwość odpokutowania za grzechy i zasłużenia na życie wieczne do końca ich dni na ziemi ${ }^{39}$.

Rozróżnienie prawa ludzkiego i objawionego prawa Bożego było stałym elementem myśli chrześcijańskiej od samych jej początków. Marsyliusz wpisywał się w tym zakresie

\footnotetext{
Tamże, I.5.11, s. 52.

35 Tamże, I.5.11, s. 51.

36 Por. tamże, I.6.1-6, s. 53-56.

37 Por. tamże, II.8.5, s. 181; tamże, II.9.1, s. 185-186; tenże, Defensor minor, 1.2, s. 172, 174; tamże, 13.8, s. $274,276$.

38 Tenże, Obrońca pokoju, II.9.3, s. 186-187.

39 Por. tamże, II.9.1, s. 185-186.
} 
w tradycję chrześcijańską, oddalał się zaś od niej w swym poglądzie na prawo naturalne, którego istnienie zdawał się na pierwszy rzut oka kwestionować, a sam termin lex naturalis uważał za zbędny. Padewczyk twierdził bowiem, iż oznaczać on może albo jak u Arystotelesa - takie statuty prawodawcy, co do których wszyscy się zgadzają, iż są prawe i należy ich przestrzegać, przy czym ich obowiązywanie zależy wówczas od ludzkiego ustanowienia, albo też, z drugiej strony, polecenie (dictamen) prawego rozumu zgodne z prawem Bożym. W pierwszym wypadku prawo naturalne sprowadza się do części prawa ludzkiego, $\mathrm{w}$ drugim zaś równoznaczne jest $\mathrm{z}$ lex divina $a^{40}$. Teoria Marsyliusza obejmuje zatem dwa rodzaje praw - ludzkie i Boskie, nie ma w niej natomiast miejsca dla prawa naturalnego, a przynajmniej dla prawa naturalnego w jego klasycznym rozumieniu.

\section{PRAWO LUDZKIE A SPRAWIEDLIWOŚĆ}

Marsyliuszowe ujęcie prawa ludzkiego jako zarządzenia prawodawcy wyposażonego w sankcję przymusu można uznać za nowatorskie na tle średniowiecznej tradycji, ponieważ akcentowało ono rolę aspektu formalnego tego prawa (upoważniony podmiot stanowiący oraz sankcja) kosztem jego treści. Taka definicja oznaczała - jak pisał Padewczyk - że nie każde prawdziwe poznanie [cognitio - przyp. M.P.] dotyczące sprawiedliwości i użyteczności spotecznej jest prawem, jeśli do jego przestrzegania nie zobowiazywatoby zniewalajace przykazanie lub nakaz ogtoszony jako przykazanie, chociaz prawdziwe poznanie sprawiedliwości i użyteczności spotecznej jest niezbędne do tego, aby prawo byto doskonate ${ }^{41}$. Z drugiej strony nawet fałszywe osądy mogą stanowić prawo, jeśli mają formę przymuszającego nakazu ustanowionego przez prawodawcę, jak w krajach barbarzyńskich. Marsyliusz wyraźnie jednak zaznacza, że są to prawa absolutnie niedoskonałe (leges non perfectae simpliciter), bo choć mają one właściwą formę, czyli sankcję przymusu, brakuje im tej wymaganej cechy (debita condicio), jaką jest należyte i prawdziwe zarządzenie tego, co sprawiedliwe (vera et debita ordinatione iustorum). Prawdziwe określenie sprawiedliwości nie jest więc warunkiem koniecznym prawa, ale jest ono wymagane, aby prawo było doskonałe ${ }^{42}$. Konstytutywnym elementem prawa jako takiego nie jest zatem jego zgodność z wyższym porządkiem normatywnym, ale właściwa forma.

40 Por. tamże, II.12.7-8, s. 209-210. Zob. także: Arystoteles, Etyka nikomachejska, przel., oprac. i wstęp D. Gromska, Warszawa 1956, 1134b, s. 185-186, Biblioteka Klasyków Filozofii.

41 Marsyliusz z Padwy, Obrońca pokoju, I.10.5, s. 67.

${ }^{42}$ Por. tamże, I.10.5, s. 68. W tym miejscu trzeba zauważyć, że autor polskiego tłumaczenia Defensor pacis bardzo niefortunnie przełoży debita et vera ordinatio iustorum jako należyte i prawdziwe ich [tj. praw przyp. M.P.] ogtoszenie, co niestety zupełnie wypacza znaczenie całego tego fragmentu i nadaje mu jednoznacznie pozytywistyczne oblicze. Bardziej adekwatne tłumaczenie tego zdania znajdujemy w przekładach angielskich - Alan Gewirth tłumaczy je jako the proper and true ordering of justice, zaś Annabel Brett jako the requisite true ordinance of what is just. Por. tenże, Defensor pacis, red. R. Scholz, Hannover 1932-1933, s. 51; tenże, Defensor Pacis, przeł. A. Gewirth, New York 2001, s. 36; tenże, The Defender of the Peace, przet. A. Brett, Cambridge 2005, s. 54. 
Postawienie przez Marsyliusza tak wyraźnego nacisku na kwestię przymusu skłania wielu badaczy do radykalnego przeciwstawiania jego koncepcji stanowisku św. Tomasza, a nawet - jak wspomniałem we wprowadzeniu - do przypisywania autorowi Defensor pacis miana prekursora pozytywizmu prawniczego ${ }^{43}$. Na pierwszy rzut oka taka radykalna interpretacja koncepcji Padewczyka może wydawać się zasadna, zwłaszcza w świetle wspomnianego wyżej stosunku autora Defensor pacis do pojęcia prawa natury. Niemniej dogłębna analiza stanowiska tego autora pokazuje, że jest ono dużo bardziej zniuansowane. Już sam fakt, że Marsyliusz mówił o relacji między prawem i sprawiedliwością w kategoriach prawdy i fałszu, pokazuje, że uznawał on istnienie jakiegoś obiektywnego wzorca sprawiedliwości. Toteż jeżeli Padewczyk istotnie głosił pozytywistyczną teorię prawa, musiał to być pozytywizm umiarkowany, bo nawet jeśli autor Defensor pacis nie widział w zgodności z ponadpozytywnym ładem normatywnym warunku koniecznego prawa, to nie kwestionował bynajmniej istnienia jakiejś formy takiego obiektywnego porządku ${ }^{44}$.

Ale również taka umiarkowanie pozytywistyczna interpretacja myśli Marsyliusza może budzić wątpliwości w kontekście jego poglądu na rolę prawa w wymierzaniu sprawiedliwości. Padewczyk był bowiem zdania, iż każdy (w miarę możliwości) osąd winien być wydawany na podstawie prawa, nie tylko dlatego, że w przeciwieństwie do ludzi jest ono wolne od emocji, ale także z tego powodu, iż w prawie zdefiniowane zostato w sposób niemal doskonaty, co jest sprawiedliwe, a co niesprawiedliwe, co korzystne, a co szkodliwe w kazdym spotecznym dziataniu cztowieka ${ }^{45}$. Co więcej, Marsyliusz twierdził, że właśnie z tego powodu podstawowym celem prawa w tym rozumieniu jest osiagnięcie tego, co sprawiedliwe w państwie i korzystne dla ogótu ${ }^{46}$. Sądzę zatem, że dla autora Defensor pacis niedoskonałe prawo zachowuje wprawdzie znamiona prawa dzięki swej właściwej formie, niemniej jednak nie pozwala ono na wydawanie prawdziwie sprawiedliwych osądów, to bowiem umożliwia jedynie lex perfecta. Krótko mówiąc, prawo nie musi być doskonałe, by można je było nazwać prawem, ale musi być doskonałe, jeśli ma realizować swój cel. Lex imperfecta nie realizuje właściwego sobie celu, a ponadto nie daje gwarancji sprawiedliwego karania występnych, dzięki któremu możliwe jest utrzymywanie w państwie pokoju. Pokój zaś jest - jak powiedziano warunkiem samowystarczalności życia, ze względu na którą istnieje wspólnota polityczna ${ }^{47}$. Istnienie wspólnoty politycznej ma zatem sens wyłącznie, jeśli prawa w niej stanowione są doskonałe, czyli sprawiedliwe. Marsyliusz nie tylko więc nie podważa istnienia jakiejś formy obiektywnego porządku normatywnego, ale de facto podtrzy-

43 Poza wymienionymi wcześniej polskimi badaczami stanowisku temu hołdują także m.in.: A. Passerin d'Entrèves, The Medieval Contribution to Political Thought. Thomas Aquinas, Marsilius of Padua, Richard Hooker, New York 1959, s. 59-65; A. Gewirth, Marsilius of Padua..., s. 134-135; M.J. Wilks, The Problem..., s. 103-104.

44 Tak właśnie pozytywizm Marsyliusza rozumie Gewirth (por. A. Gewirth, Marslius of Padua..., s. 134-135).

45 Marsyliusz z Padwy, Obrońca pokoju, I.11.3, s. 70. Por. tamże, I.11.1, s. 68-69; tamże, I.11.6, s. 73-74.

46 Tamże, I.11.1, s. 68.

47 Por. tamże, I.4.1, s. 45. Zob. także: Arystoteles, Polityka, 1252b, s. 27. 
muje tradycyjne i charakterystyczne dla prawnonaturalizmu przekonanie o konieczności uzgodnienia prawa ludzkiego z tym porządkiem.

Pozostaje jeszcze rozważyć kwestię rozpoznawania obiektywnego ładu normatywnego, jaki zakładał Marsyliusz, oraz jego implementacji do norm ludzkich, czyli - mówiąc językiem Padewczyka - zagadnienie doskonalenia prawa. Wedle autora Defensor pacis doskonałe określenie tego, co sprawiedliwe, przekracza możliwości jednego człowieka, a być może i wszystkich ludzi w danej epoce. Marsyliusz twierdził jednak, że prawo ludzkie może osiągnąć doskonałość, ponieważ nie jest ono dziełem jednego człowieka ani nawet jednej epoki, ale wynika z doświadczeń wielu pokoleń ludzi - to, co powiedzieli na ten temat [tj. sprawiedliwości i korzyści społecznej - przyp. M.P.] pierwsi wynalazcy prawa oraz wszyscy ludzie z tej samej epoki przestrzegajacy tych praw, sprowadza się do rzeczy skromnych i niedoskonatych, które zostaty następnie uzupetnione wktadem ich potomnych ${ }^{48}$. Krótko mówiąc, lex perfecta jest owocem kumulatywnego rozwoju ludzkiej wiedzy o tym, co sprawiedliwe, w toku którego niedoskonałe określenia pierwszych odkrywców były systematycznie poprawiane czy uzupełniane przez ich następców. To jednak oznacza w istocie, iż dla Marsyliusza prawa państwowe zasadniczo są doskonałe, bowiem niemal wszędzie stanowią one dorobek wielopokoleniowych starań o ustanowienie sprawiedliwego porządku. Każda communitas perfecta zawiera zatem leges perfectae. Prawo niedoskonałe cechuje jedynie kraje barbarzyńskie ${ }^{49}$.

Podsumowując powyższe rozważania, Marsyliusza z Padwy o tyle trudno nazwać ojcem stanowiska pozytywistycznego, że de facto uznawał on konieczność uzgodnienia prawa ludzkiego z pewną formą obiektywnego porządku normatywnego będącego ekwiwalentem prawa naturalnego. Ów ekwiwalent niewątpliwie różnił się od lex naturalis $\mathrm{w}$ ujęciu św. Tomasza, przede wszystkim z uwagi na jego bardziej laickie oblicze. Padewczyk na żadnym etapie swoich rozważań nie odnosił pojęcia sprawiedliwości do Boga, nigdzie nie sugerował też Boskiej genezy tego, co sprawiedliwe. Ponadto o ile św. Tomasz uważał, że każdy człowiek może rozpoznać prawo naturalne w swoim rozumie, albowiem jest ono istniejącym udziałowo w nim jako istocie rozumnej prawem wiecznym, o tyle Marsyliusz wykluczał taką możliwość, ponieważ dochodzenie do pełnej wiedzy o tym, co sprawiedliwe, dokonuje się wyłącznie dzięki kumulacji doświadczeń wielu pokoleń. Niemniej jednak obaj myśliciele zgadzali się, iż prawo ludzkie winno być oparte na normach wyższego rzędu, że musi być sprawiedliwe i korzystne dla wspólnoty. Z tej racji koncepcję Padewczyka uznać należy w moim odczuciu za przykład umiarkowanego i zlaicyzowanego prawnonaturalizmu.

$\mathrm{Z}$ drugiej strony nie ulega wątpliwości, że w swych rozważaniach nad naturą prawa Padewczyk bardziej niż Akwinata akcentował rolę czynnika formalnego w postaci przymusu i w tym wymiarze jego stanowisko istotnie stanowiło pewien krok w kierunku późniejszych ujęć pozytywistycznych. Owo bardziej dobitne podkreślanie przez Marsyliusza znaczenia formy pozwalało mu z jednej strony pozbawić prawo kościelne miana prawa we właściwym znaczeniu, z drugiej zaś wzmocnić autonomię prawa ludz-

48 Marsyliusz z Padwy, Obrońca pokoju, I.11.3, s. 70.

49 Por. G. Garnett, Marsilius of Padua and "the Truth of History”, Oxford 2006, s. 66. 
kiego poprzez zminimalizowanie groźby kwestionowania go w oparciu o niewłaściwą treść $^{50}$. I tu jednak trudno mówić o radykalnej różnicy między oboma myślicielami, bo przecież także św. Tomasz zwracał uwagę na konieczność poparcia prawa siłą przymuszającą (vis coactiva), a nawet skłonny był uznać, że również niesprawiedliwe prawo (lex iniqua) nosi znamiona prawdziwego prawa, ponieważ daje ono pewien porządek władzy i przynajmniej w tym sensie wywodzi się z prawa wiecznego ${ }^{51}$.

\section{PRAWO LUDZKIE A PRAWO BOŻE}

Osobną kwestię, której nie można pominąć, omawiając koncepcję prawa Marsyliusza z Padwy, stanowi relacja lex humana do Objawienia, czyli prawa Bożego. Autor Defensorpacis nie traktował wszakże tego problemu w kategoriach filozoficznych, albowiem Objawienie z definicji jest (przynajmniej w części) niedostępne naturalnemu poznaniu ludzkiemu i jako takie stanowi ono przedmiot teologii, a nie filozofii ${ }^{2}$. Zagadnienie relacji między tymi dwoma porządkami normatywnymi nie ma przeto żadnego znaczenia w pogańskich wspólnotach politycznych, odgrywa natomiast kapitalną rolę w rzeczywistości państwa chrześcijańskiego, do której w swych pismach odnosił się Marsyliusz.

W tej kwestii Padewczyk również nie odbiegał daleko od tradycji chrześcijańskiej, twierdził bowiem, że prawo Boże nie tylko nie podważa konieczności istnienia prawa ludzkiego, ale wręcz je postuluje. Lex divina nie reguluje przecież sporów międzyludzkich i nie mówi nic o ich doczesnym rozsądzaniu, a skoro $w$ prawie Easki nie zostaty dane specjalne nakazy regulujace stosunki między ludźmi na tym świecie, wnosić trzeba, że powinny one zostać określone jedynie przez prawa ludzkie oraz maja być egzekwowane przez sędziów posiadających autorytet pochodzacy od świeckiego prawodawcy ${ }^{53}$. Wedle Marsyliusza nie świadczyło to jednak bynajmniej o niedoskonałości prawa Bożego, albowiem jego racją nie było i nie jest rozsądzanie spraw doczesnych, ale prowadzenie ludzi do wiecznego szczęścia. Zostato ono nam dane - pisał - w tym wtaśnie celu, a nie do rozstrzygania spornych spraw ludzkich i wprowadzania spotecznej równości lub zapewnienia każdemu należnej miary do prowadzenia samowystarczalnego życia na tym świecie. Chrystus bowiem nie przyszedt na świat po to, by porzadkować

50 Por. J. Canning, Ideas of Power..., s. 104; tenże, The Role of Power..., s. 29.

51 Por. św. Tomasz z Akwinu, Summa Theologiae, I-II, q. 90, a. 3, ad 2; tamże, q. 93, a. 3, ad 2; tamże, q. 96, a. 5.

52 Por. L. Strauss, Marsyliusz z Padwy, [w:] Historia filozofii politycznej, red. L. Strauss, J. Cropsey, red. nauk. P. Nowak, M. Wiśniewski, przed. do wyd. pol. P. Nowak, Warszawa 2010, s. 296-298.

53 Marsyliusz z Padwy, Obrońca pokoju, II.9.10, s. 192. Dodajmy jednak, że Marsyliusz był świadom, iż takie odesłanie do prawa ludzkiego nie miało miejsca w Starym Prawie (prawie Mojżeszowym), które normowało także doczesne stosunki między ludźmi. Prawo to wiązało jednak jedynie naród Izraelski do czasu przyjścia Mesjasza, od którego to momentu nie wiąże już ono nikogo. Dualizm lex humana - lex divina pojawił się wszak wedle Padewczyka wraz z Objawieniem Chrystusowym (por. tamże, II.9.9, s. 191; G. Garnett, Marsilius of Padua..., s. 57-59). 
tego rodzaju sprawy ze względu na życie doczesne, lecz wytacznie ze względu na życie w przysztym świecie $e^{54}$.

Co więcej jednak, Marsyliusz stał na stanowisku, że prawo ewangeliczne wprost nakazuje przestrzeganie legis humanae, aczkolwiek nie bezwarunkowo, ponieważ wymaga jego zgodności z normami Bożymi. Zdaniem Padewczyka sam Chrystus nakazat wszystkim przestrzeganie praw ludzkich i postuszeństwo wobec wtadców, którzy rzadza wedle tych praw, oczywiscie w tych sprawach, które nie sprzeciwiaja się prawu wiecznego zbawienia ${ }^{55}$. Marsyliusz stwierdzał wobec tego jednoznacznie, że w wypadku ewentualnej kolizji norm ludzkich z prawem ewangelicznym należy zawsze uznawać wyższość tego ostatniego - jeśli prawo Boże nakazuje coś uczynić bądź zaniechać, czego uczynienia lub zaniechania nie nakazuje prawo ludzkie (a raczej nakazuje lub przyzwala przeciwnie), wówczas należy przestrzegać nakazu prawa Bożego, wzgardzając przeciwnym mu nakazem czy przyzwoleniem ludzkim, ponieważ to nakaz Bożego, a nie ludzkiego prawa zawiera nieomylna prawdę ${ }^{56}$ [tłumaczenie własne - przyp. M.P.]. Można więc wnosić, że prawo państwowe, jeśli ma być przestrzegane, musi być dostosowane do prawa Bożego. Dodajmy jednak, że Marsyliusz liczył się oczywiście z możliwością, a nawet nieuchronnością istnienia takich reguł prawa ludzkiego, które dopuszczają wykonywanie czynów zakazanych prawem Bożym, jak choćby w przypadku cudzołóstwa czy pijaństwa. Sądził on jednak, że w takich przypadkach nie można mówić o rzeczywistej sprzeczności (repugnantia) między oboma porządkami normatywnymi, ta bowiem zachodzi tylko wtedy, gdy jedna i ta sama czynność jest nakazana w świetle jednego prawa, a zakazana przez drugie ${ }^{57}$.

Tak jednoznaczne przyznanie prawu Bożemu prymatu nad normami państwowymi wydaje się stanowić istotny wyłom w koncepcji Marsyliusza, ponieważ ujęcie takie musiało pociągać za sobą uznanie konieczności podporządkowania działalności legislacyjnej państwa nauczaniu Kościoła. Jednak problem ten przedstawia się zupełnie inaczej, jeśli weźmiemy pod uwagę poglądy Padewczyka na naturę Kościoła i jego instytucji. Szczegółowa analiza eklezjologicznych koncepcji Marsyliusza wykracza oczywiście poza ramy niniejszego artykułu. W tym miejscu ograniczę się jedynie do uwagi, iż eklezjologię autora Defensor pacis cechuje daleko posunięty antyklerykalizm polegający na radykalnej deprecjacji roli kleru (a w szczególności papieża) w życiu wspólnoty kościelnej, w szczególności zaś w wydawaniu wiążących interpretacji prawa Bożego.

54 Marsyliusz z Padwy, Obrońca pokoju, II.9.12, s. 192.

55 Tamże, II.9.9, s. 191.

56 Tenże, Defensor minor, 13.6, s. 274: Est adhuc etiam advertendum, quod si praecipit lex divina fiendum vel omittendum aliquid, quod fieri vel omitti non praecipiat lex humana, sed potius oppositum praecipiat, vel permittat, debet servari legis divinae praeceptum, humana lege seu eius opposito praecepto vel permissio contempto seu dimisso, quoniam praeceptum legis divinae infallibilem continet veritatem, humanae vero legis non sic.

57 Por. tenże, Obrońca pokoju, II.13.2, s. 214-215; tenże, Defensor minor, 15.8-9, s. 298, 300, 302. Ten swoisty permisywizm prawa ludzkiego przejawiający się w przyzwalaniu na popełnianie pewnych czynów zakazanych przez prawo Boże uznawał również Akwinata. Por. św. Tomasz z Akwinu, Summa Theologiae, I-II, q. 96, a. 2. 
W opinii Padewczyka do oficjalnej wykładni legis divinae nie jest uprawniony żaden kapłan ani nawet zgromadzenie duchownych, ale ogół wiernych lub ciało reprezentujące ów ogól. Tylko sobór powszechny - pisał jednoznacznie - albo jego znamienitsza większość, czyli wybrana część, może rozstrzygać wątpliwe sensy w prawie boskim, w szczególności dotyczące tzw. artykutów wiary chrześcijañskiej, a także tych prawd, których wyznawanie jest konieczne do osiagnięcia zbawienia wiecznego. Żadne partykularne kolegium ani indywidualne osoby, niezależnie od tego, jakie piastowatyby stanowiska, nie posiadaja wyżej wymienionej wtadzy ${ }^{58}$. Wbrew pozorom było to stanowisko niesłychanie radykalne i bezprecedensowe w całej historii Kościoła. Rewolucyjność tego poglądu nie tkwiła jednak w samym przyznaniu soborom zwierzchniej pozycji w Kościele. Tym, co przesądzało o radykalizmie projektu Marsyliusza, było dopuszczenie laikatu do udziału w obradach concilium generale, a nawet przyznanie mu decydującego wpływu na orzeczenia soborowe. Padewczyk pisał bowiem, że jeśli kaptani spieraja się między soba na temat prawd, w które trzeba wierzyć dla osiagnięcia zbawienia wiecznego, to znamienitsza część wierzacych powinna rozstrzygać, która strona spośród nich jest $z$ drowsza $a^{59}$.

Taka deprecjacja roli kleru na soborze powszechnym pozwalała wyswobodzić prawa stanowione w poszczególnych wspólnotach politycznych z wpływów duchowieństwa, ale sama w sobie nie mogła zagwarantować pewnej niezależności państwowych porządków prawnych od orzeczeń soborowych. Marsyliusz starał się w związku z tym zagwarantować jak największy wpływ państw na obrady ciała reprezentującego ogół wierzących chrześcijan. Przede wszystkim przyznawał chrześcijańskim wspólnotom politycznym całkowitą kontrolę nad procesem wyboru ich delegatów na concilium generale. To prawodawcy ludzcy poszczególnych państw mieli bowiem jego zdaniem decydować, zapewne w zgodzie z ogólnymi wytycznymi sformułowanymi przez cesarza, o sposobie elekcji przedstawicieli przez grupy wiernych, a także wysyłać na sobór swoich świeckich reprezentantów ${ }^{60}$. I choć uczestnictwo tych ostatnich w obradach concilium uzasadniał Padewczyk możliwością podejmowania przez to ciało decyzji niezwiązanych z prawem Bożym, ale mających wpływ na pokój i pożytek wiernych na tym świecie, możemy się domyślać, że rolą owych delegatów prawodawcy miało być reprezentowanie na soborze politycznych interesów civitas ${ }^{61}$.

Marsyliusz stał ponadto na stanowisku, że sobór winien znajdować się pod pełnym nadzorem władzy politycznej w osobie cesarza, któremu przypisywał on wyłączną kompetencję do zwoływania tego ciała, powierzając zarazem w jego ręce troskę o właściwe celebrowanie i doprowadzenie do końca obrad soborowych ${ }^{62}$. W tym kontekście należy uznać za znamienne, iż mówiąc o cesarzu, Marsyliusz wspominał (przynajmniej na kartach Defensor pacis) jedynie o jego funkcjach eklezjalnych, całkowicie zaś pomijał jego

\footnotetext{
58 Marsyliusz z Padwy, Obrońca pokoju, III.2.2, s. 430. Por. tamże, II.18.8, s. 286.

59 Tamże, II.20.5, s. 295. Por. tamże, II.20.13, s. 298.

60 Por. tamże, II.20.2, s. 293-294; tamże, II.21.1, s. 299-300.

61 Por. tamże, II.20.2-3, s. 293-295.

62 Por. tamże, II.18.8, s. 286-287; tamże, II.21.1, s. 299-300.
} 
znaczenie polityczne. Padewczyk zdaje się w ten sposób sprowadzać rolę imperatora do sprawowania zwierzchnictwa nad naczelną instytucją Kościoła powszechnego, a więc soborem, dzięki czemu poszczególne państwa mogły w zasadzie zachować pełną niezależność od Kościoła. Cesarz jest oczywiście władcą w swoim partykularnym civitas, czyli w imperium rzymskim, gdzie pełni zarazem funkcję prawodawcy. Poza nim jest on jednak tylko łącznikiem między pluralistycznym porządkiem politycznym a uniwersalistycznym porządkiem eklezjalnym, odgrywającym - jak możemy przypuszczać - rolę reprezentanta poszczególnych państw, w imieniu których kontroluje on działalność Kościoła na poziomie ponadpaństwowym, zabezpieczając tym samym niezależność civitates $\mathrm{i}$ ich wewnętrznych porządków prawnych.

W świetle powyższych ustaleń formułowane przez Marsyliusza przekonanie o konieczności podążania za prawem Bożym w razie ewentualnej kolizji z normami legis humanae jawi się jako pozbawiony realnego znaczenia frazes, trudno bowiem mówić o możliwych sprzecznościach między oboma porządkami normatywnymi, jeśli dawca prawa ludzkiego jest zarazem de facto organem dokonującym nieomylnej wykładni legis divinae albo przynajmniej sprawuje nad takim organem pełną kontrolę ${ }^{63}$. Należy więc przyjąć, że na gruncie teorii Marsyliusza normy prawa ludzkiego są niejako z zasady zgodne z prawem Bożym w państwie chrześcijańskim. Civitas nie jest zatem związane orzeczeniami Kościoła w kwestiach prawa Bożego, ale raczej samo narzuca Kościołowi wiążące interpretacje tego prawa ${ }^{64}$.

\section{WNIOSKI}

Marsyliusz sformułował oryginalną koncepcję prawa różniącą się od innych ujęć średniowiecznych, choć nie w takim stopniu, jak sądzą niektórzy badacze. Wbrew pozorom jego koncepcja prawa ludzkiego nie odbiega radykalnie od stanowiska św. Tomasza z Akwinu, mimo iż Padewczyk niewątpliwie przywiązywał większą wagę do formalnego wymiaru prawa, a zwłaszcza do kwestii przymusu. Podkreślenie kluczowego znaczenia tego elementu pozwoliło Marsyliuszowi całkowicie zakwestionować istnienie

63 Por. A. Wójtowicz, Model wtadzy państwowej..., Katowice 1977, s. 81-82.

64 W tym świetle należy chyba czytać dość osobliwy fragment Defensor pacis, w którym Marsyliusz zdaje się podawać w wątpliwość istnienie takich czynów, które mogłyby być dopuszczane lub nakazane z punktu widzenia prawa Bożego, ale zakazane przez prawo państwowe, choć oczywiście uznawał on, jak wspomniałem wyżej, istnienie przypadków odwrotnych, a więc czynów zakazanych przez Boga, choć dopuszczonych przez państwo. Marsyliusz pisał: Jeśli jedno i drugie prawo pozwala na jakieś dziatania, to i dziatania te bedą dopuszczalne w obu prawach. Jeśli zaś będą one zakazane w obu, to i dziatania te będą niedopuszczalne $w$ jednym $i$ drugim prawie. Natomiast problem, czy wolno wedle prawa Bożego czynić coś lub czegoś zaniechać, co jest przez prawo ludzkie nakazane lub zakazane i na odwrót [quemadmodum econverso, przez co rozumieć należy raczej „jak to ma miejsce na odwrót” - przyp. M.P.], pozostawiamy nierozstrzygnięty, ponieważ nie należy on do tematu obecnych rozważań. Wiadomo jednak, że prawo ludzkie zezwala na wiele rzeczy, jak na przyktad na cudzotóstwo, pijaństwo i inne występki, które sq zakazane przez prawo Boże (Marsyliusz z Padwy, Obrońca pokoju, II.13.2, s. 214-215). Istotnie, jeśli państwo sprawuje pełną kontrolę nad interpretacją legis divinae, wówczas nie ma mowy o dopuszczaniu przez prawo Boże tego, co jest zakazane przez państwo. 
prawa kościelnego, a zarazem wzmocnić autonomię prawa ludzkiego. Tę samą funkcję pełniła zresztą zakamuflowana koncepcja ekwiwalentu prawa naturalnego, wyraźnie już odmienna od ujęcia św. Tomasza i innych myślicieli średniowiecznych ${ }^{65}$. Dokonując laicyzacji pojęcia sprawiedliwości, Marsyliusz de facto pozbawiał kler tytułu do osądzania treści prawa ludzkiego i jej zgodności z porządkiem ponadpozytywnym. Z kolei proponowane przez Padewczyka ujęcie prawa Bożego i jego relacji do lex humana całkowicie mieściło się w ramach chrześcijańskiej tradycji. Tym, co radykalnie od niej odbiegało, było pozbawienie duchowieństwa kompetencji do wydawania wiążących interpretacji tego prawa i powierzenie jej ogółowi wiernych reprezentowanemu przez sobór powszechny, w którego obradach decydującą rolę odgrywać mieli świeccy. Wywyższenie laikatu kosztem kleru i poddanie soborów kontroli ze strony władzy politycznej było równoznaczne z faktycznym uniezależnieniem norm ludzkich od prawa Bożego, a władzy państwowej od duchowieństwa.

\section{BIBLIOGRAFIA}

\section{Źródła}

Arystoteles, Etyka nikomachejska, przel., oprac. i wstęp D. Gromska, Warszawa 1956, Biblioteka Klasyków Filozofii.

Arystoteles, Polityka, przel., wstęp i koment. L. Piotrowicz, wstęp M. Szymański, Warszawa 2008.

Marsiglio of Padua, Writings on the Empire. "Defensor minor" and "De translatione Imperii", przeł. i red. C.J. Nederman, Cambridge-New York 2006.

Marsile de Padoue, Defensor minor, [w:] tenże, Oeuvres mineures, red. C. Jeudy, J. Quillet, Paris 1979, Sources d'Histoire Médiévale.

Marsilius of Padua, The Defender of the Peace, przel. A. Brett, Cambridge 2005.

Marsilius of Padua, Defensor Pacis, przeł. A. Gewirth, New York 2001.

Marsilius von Padua, Defensor pacis, przeł. R. Scholz, Hannover 1932-1933.

Marsyliusz z Padwy, Obrońca pokoju, przeł., oprac. i wstęp W. Seńko, Kęty 2006, Biblioteka Europejska - Antyk.

Św. Tomasz z Akwinu, Summa Theologiae, [online] www.corpusthomisticum.org, 21 XII 2014.

\section{Literatura}

Baszkiewicz J., Myśl polityczna wieków średnich, Poznań 2009, Czas i Myśl.

Briguglia G., The Minor Marsilius. The Other Works of Marsilius of Padua, [w:] A Companion to Marsilius of Padua, red. G. Moreno-Riaño, C.J. Nederman, Leiden 2012, Brill's Companions to the Christian Tradition, Vol. 31.

Canning J., A History of Medieval Political Thought, 300-1450, London-New York 1996.

Canning J., Ideas of Power in the Late Middle Ages, 1296-1417, New York-Cambridge 2011.

65 Por. F. Maiolo, Medieval Sovereignty..., s. 204. 
Canning J., The Role of Power in the Political Thought of Marsilius of Padua, „History of Political Thought" 1999, Vol. 20, nr 1.

Condren C., Marsilius of Padua's Argument from Authority. A Survey of Its Significance in the „Defensor Pacis”, „Political Theory” 1977, Vol. 5, nr 2.

Courtenay W.J., Marsilius of Padua at Paris, [w:] A Companion to Marsilius of Padua, red. G. Moreno-Riaño, C.J. Nederman, Leiden 2012, Brill's Companions to the Christian Tradition, Vol. 31.

Dubel L., Koncepcja wtadzy prawodawczej Marsyliusza z Padwy, [w:] Konstytucyjny ustrój państwa. Ksiega jubileuszowa profesora Wiestawa Skrzydty, red. T. Bojarski, E. Gdulewicz, J. Szreniawski, Lublin 2000.

Garnett G., Marsilius of Padua and „the Truth of History”, Oxford 2006.

Gewirth A., Marsilius of Padua and Medieval Political Philosophy, New York 1951, Marsilius of Padua, the Defender of Peace, nr 1.

Godthardt F., The Life of Marsilius of Padua, [w:] A Companion to Marsilius of Padua, red. G. Moreno-Riaño, C.J. Nederman, Leiden 2012, Brill's Companions to the Christian Tradition, Vol. 31.

Lee H.-Y., Political Representation in the Later Middle Ages. Marsilius in Context, New York 2008.

Maiolo F., Medieval Sovereignty. Marsilius of Padua and Bartolus of Saxoferrato, Delft 2007.

Moreno-Riaño G., Nederman C.J., Marsilius of Padua's Principles of Secular Politics, [w:] A Companion to Marsilius of Padua, red. G. Moreno-Riaño, C.J. Nederman, Leiden 2012, Brill's Companions to the Christian Tradition, Vol. 31.

Nederman C.J., Community and Consent. The Secular Political Theory of Marsiglio of Padua's „Defensor Pacis”, Lanham 1995.

Nederman C.J., Editor's Introduction, [w:] Marsiglio of Padua, Writings on the Empire. „Defensor minor" and „De translatione Imperii”, przeł. i red. C.J. Nederman, Cambridge-New York 2006.

Nederman C.J., Knowledge, Consent and the Critique of Political Representation in Marsiglio of Padua's „Defensor Pacis”, „Political Studies” 1991, nr 39.

Nederman C.J., Marsyliusz z Padwy, [w:] Myśliciele polityczni. Od Sokratesa do wspótczesności, red. D. Boucher, P. Kelly, przeł. A. Dąbrowska, T. Sieczkowski, Kraków 2008, Polityka Wydawnictwo Uniwersytetu Jagiellońskiego.

Nederman C.J., Nature, Justice, and Duty in the „Defensor Pacis”. Marsiglio of Padua's Ciceronian Impulse, „Political Theory” 1990, Vol. 18, nr 4.

Passerin d'Entrèves A., The Medieval Contribution to Political Thought. Thomas Aquinas, Marsilius of Padua, Richard Hooker, New York 1959.

Pieniążek A., Suwerenność - problemy teorii i praktyki, Warszawa 1979.

Strauss L., Marsyliusz z Padwy, [w:] Historia filozofii politycznej, red. L. Strauss, J. Cropsey, red. nauk. P. Nowak, M. Wiśniewski, przed. do wyd. pol. P. Nowak, Warszawa 2010.

Tierney B., Religion, Law, and the Growth of Constitutional Thought, 1150-1650, Cambridge 2008.

Ullmann W., A History of Political Thought. The Middle Ages, Harmondsworth 1968.

Wielomski A., Teokracja papieska 1073-1378. Myśl polityczna papieży, papalistów i ich przeciwników, Radzymin-Warszawa 2011, Biblioteka Konserwatyzm.pl. 
Wilks M.J., The Problem of Sovereignty in the Later Middle Ages. The Papal Monarchy with Augustinus Triumphus and the Publicists, Cambridge 2008.

Wójtowicz A., Model wtadzy państwowej Marsyliusza z Padwy, Katowice 1977, Prace Naukowe Uniwersytetu Śląskiego w Katowicach, nr 187.

Żyro T., Wola polityczna. Siedem prób z filozofii praktycznej, Warszawa 2008, Wspótczesna Myśl Humanistyczna. Polskie Spojrzenia.

Mgr Mieszko PAWLAK - absolwent politologii i filozofii na Uniwersytecie Jagiellońskim, doktorant w Katedrze Filozofii Polityki w Instytucie Nauk Politycznych i Stosunków Międzynarodowych UJ. Interesuje się filozofią i teologią polityczną oraz historią myśli politycznej, ze szczególnym uwzględnieniem myśli średniowiecznej. Obecnie jest w trakcie przygotowywania pracy doktorskiej poświęconej doktrynie koncyliaryzmu w Polsce w XV wieku. 